\title{
STATE OF EXCEPTION THROUGH RASISME IN GO SET A WATCHMAN IN AGAMBEN'S POLITICAL PHILOSOPHY
}

\author{
Damay Rahmawati \\ Universitas Duta Bangsa, Jalan Pinang Raya no 47, Grogol, Sukoharjo, Indonesia \\ Damay_rahmawati@udb.ac.id \\ Ramadhani Ardianto Karsa Sunaryono \\ Universitas Duta Bangsa, Jalan Pinang Raya no 47, Grogol, Sukoharjo, Indonesia \\ Ramadhani_Karsa@udb.ac.id
}

\author{
Mira Utami \\ UIN Syarif Hidayatullah Jakarta, Indonesia \\ anggongsaid@gmail.com
}

Accepted: 2021-06-15, Approved: 2021-07-01 , Published: 2021-07-05

\section{ABSTRACT}

This study aims to see racism in the novel Go Set a Watchman by Harper Lee as state of exception; a political philosophy of Agamben. Agamben's idea of state of exception is used in this study as the theoretical framework. This research specifically reveals how racism becomes part of state of exception in American society around 1960s when the novel was written. The analysis focuses on issues of racism in American society as depicted in the novel. The issue of racism is taken with the aim of analyzing state of exception in USA, in dealing with racial discrimination. After analyzing the issues of racism and state of exception in the novel, this study reveals that racism in American society is politically structured. The finding of this study is the discrimination experienced by lower class citizens who are dominated by black people, as the impact of state of exception which affects their citizenship rights.

\section{Keywords: Sociological Criticism; Biopolitic; State of Exception; Racism.}

\section{INTRODUCTION}

Literature can get quite an impact from human life, social conditions of people as a part of society. Go Set A Watchman is a novel written by Harper Lee, the infamous writer of To Kill a Mockingbird which put a deep influence in the area of racial literature. Go Set A Watchman was published in 2015, theoretically the root of To Kill a Mockingbird which was published in 1960. Go Set A Watchman actually the first writing of Lee, but got rejected because of the unfeasibility assumption. Lee then revised the script into To Kill a Mockingbird. Later, the first failed script got the attention that finally being published as the sequel of To Kill $a$
Mockingbird. The novel firmly depicts the socio-political condition of USA around 1960s. It becomes an interesting point to be analyzed from the perspective of genetic structuralism paradigm, for the doublestandard politic practices of USA as a democratic country. From Agamben's point of view (2019), the theory of Homo Sacer and the concentration camp, the Muselman, dan the Trinitarian Oikonomia and the Acclamations are paradigms (15). Thus, the paradigms are used to analyse the novel Go Set A Watchman, to find the different perspective of sociological literature based on Agamben's thoughts of socio-political issues.

There are some differences between To Kill a Mockingbird and Go Set A 
Watchman. The interesting differences including the characterization, point of view, and the issues. The good lawyer Atticus Finch in To Kill a Mockingbird becomes the antagonist in Go Set A Watchman. Then, the character Jean Louise point of view as a little girl in To Kill a Mockingbird shifted into adult Jean Louise. Further difference is the well-done narration of social and political matters in USA, especially at the southern parts, as the main issue.

The story of Jean Louise in Go Set A Watchman started when she went back to her hometown, Maycomb County Montgomery from New York. Day by day, Jean Louise found more and more racism practices as she first saw a racism flyer that led her to sneak into a racist-gathering, where her biggest disappointment started.

Jean Louise admiration towards her father whom known as a wise and righteous lawyer was falling apart when she found him among the member of Maycomb citizen council, in a meeting full of criticisms toward black people. She also found her lover, Hank, joined her father there, added salts to her wound. A lot of changes happened in Maycomb, particularly in Jean Louise family and her surroundings since she left to live and work in New York. It becomes the plot of Go Set a Watchman, that present the socio-political situation in southern USA, as well as the racism presentation in the society. Racial discrimination after all is one of social issues that still becomes a main problem in modern society. The issues generates from the unacceptance of physical traits of certain races, such as skin color, hair color, physical form/body shape, and other biological traits (Ariesta \& Muliastuti, 2017: 48)

As the background of Go Set A Watchman, the socio-political conditions of USA in the 1960s become the fundamental to discover the potential factors that shape social character collectively or individually. Issues that become the focus of this research are racism, gender, religion, education, and economy.

In 1960, 100 years after the end of slavery in USA, discrimination against black people was still viscous within society. Discrimination can be defined as different treatment towards other, by intention or spontaneous, and distinction of interactions without basis (Reskin, 2012: 19). It then resulted in the raise of organizations that aim to protect the rights of African Americans who still struggling against discrimination. Based on the phenomenon could be concluded that the sovereignty of USA government to its citizens at that time was through full protection to the rights of white people and made exceptions to the of black people.

The theory used in this study is a political philosophy theory of Giorgio Agamben. According to Agamben, based on international law, state is an individual that must have several qualifications such as permanent population, clear boundaries, governmental system, and the ability to build relationships with other countries. As a country, state holds responsibility towards its citizens. The responsibilities of a state are:

1. Providing the space for its citizens to be actively participate in decision making of political issues

2. Providing security for its citizens against threats and crimes from inside and outside.

3. Enforcing justice for its citizens to get fair and equal treatment, without discriminations.

4. Providing basic social services, make possible for its citizens to have such a proper living.

5. Constructing infrastructure to support economy, and make regulations aimed at equitable economic life.

All five things above should be fulfilled to build a state that is approved by international law (Grotenhuis, 2016: 25). 
The existence of state is always related to the existence of nation. Essentially, nation and state are different in definition. Nation is an imaginary political community that is limited and sovereign. However, both have an overlapping relationship. It can be concluded then, that a nation-state defined as a population within territorial boundaries led by a leader with the authority of sovereignity (Grotenhuis, 2016: 27). Even though both of them are closely related, there are some significant differences between nation and state. The differences lie in the appearance of the two. State is an institution, structure, and system whereas the nation is an identity. State is a collective objectivity while nation is a collective subjectivity (Grotenhuis, 2016: 28). The sovereignty itself according to Agamben is a machine of power which he called government. In traditional way, sovereignty means power in a territory. Sovereignty can also be taken as political theology (Murray \& Whyte, 2011: 180). Thus, nation and state both have their respective roles in shaping individuals who have identity and character before international law.

Furthermore, Agamben provides a more vivid picture of how sovereignty has been defined so far as a natural force to do anything upon anyone (Murray \& Whyte, 2011: 181). In other word, the paradigm of the act of government was the mysterious administration of the world, involving the calculation and partition of power and its exclusion (Liu, 2015: 87).

At the point of power, Agamben shares the same point of view with Foucault's thought of dispositif, or known as apparatus. The apparatus is physical activator of sovereignty power. In Foucaults's thought, apparatus represents the network of power relations which articulates how a power manifests itself not based upon classical conceptions of sovereignty. Through the apparatus, human being is transformed into both a subject, and an object, of power relations.
Meanwhile, Agamben stated that apparatus is literally anything that has the capacity to capture, orient, determine, intercept, model, control, or secure the gestures, behaviours, opinions, or discourses of living beings. Therefore, not only institutions like prisons, mad houses, the panopticon, schools, confession, factories, disciplines, juridical measures, and so on (whose connection with power is in a certain sense evident), but also the pen, writing, literature, philosophy, agriculture, cigarettes, navigation, computers, cellular telephones, even language itself, which is perhaps the most ancient of apparatuses (Frost, 2019: 19). There said that apparatus can be seen as a tool, or a concept of tools that have the ability to control and captivate, refers to how it can impair social works.

Hereinafter, it's known that through the state of exception, politics then produce and reproduce bare life. Bare life is a life that is stripped down from its own form, and seen as a kind of life that falls within ethical and political boundaries (Murray \& Whyte, 2011: 180). Western culture has been exploited to mark racialised bodies as nonhuman by projecting animality onto socially subjugated groups, these individuals are framed as neither animal nor human life, but bare life (Brown, 20 17: 3). In further observation, Brown (2017) mentioned that Agamben traces how modern biopolitical states have utilized the state of exception that causes the production of bare life in order to justify the abandonment and potential destruction of those individuals subject to their control (5). Agamben constructing sovereignty as an omnipresent figure. Instead, the retreat of sovereignty corresponds to the dislocation of the state of exception and of the law as the privileged categories that inform the political production of bare life (Villamizar, 2014: 81).

Then, the other principal of Agamben's socio-political theory is the biopolitical theory. In general, biopolitics can be interpreted as the inclusion of social 
life in political calculations. Biopolitics is usually used to suppress or prohibit, in an effort to regulate life. In biopolitics, there is biopower, as the analysis of the strength of discipline and normalization mechanisms which formed to change and influence the life of human (Frost, 2010: 547).

Agamben mentions the biopolitics theory from his point of view in one of his book, Homo Sacer. Basically, Agamben's idea is to know how a state sovereignty is created (Murray \& Whyte, 2011: 124). Then it's obvious that the biopolitical logic carried out by sovereignty uses the logic of neglect and prohibition originates from the history of western democracy since the ancient times until now. Today, the exception has become the working rule for sovereignty (Murray \& Whyte, 2011: 181). In short, sovereignty lies on the state's decisions regarding public order and security through laws. Thus, biopolitic can be interpreted as the result of state sovereignty in its efforts to dominate and perform disciplinary control. The domination and disciplinary control are performed through the laws and allow it to control citizens life.

Citizenship, in its relation to the state as a subject, can be obtained based on heredity, place of birth, marriage, and other reasons that can be accepted for citizenship application to the state. There are at least three types of citizenship that can be identified. The first is social citizenship which defined as a sense of belonging or as a part of a country and actively participating in social life. The second is political citizenship, which includes voting rights and involvement in politics. The later is civilian citizenship that recognized as part of the state and get the state to protect the rights (Gordon-Zolov \& Robin Rogers, 2010: 13)

Sovereignty and bare life have a relationship that makes them inseparable, because sovereignty obtains its independence by producing bare life. In politics, there is a condition that allows the sovereignty to produce bare life, which said as state of exception. State of exception is the principal activity of sovereignty to explain how politics and law are fully related each other. Agamben argues that political thinking is about the possibility of rule of law suspension in state of exception. The state has suspended its own rule of law to maintain the rule of law itself as a routine (Murray \& Whyte, 2011: 185). The state of exception is intrinsically related to sovereignty construction and activity, where sovereignty is the determinant in state of exception. In fact, exceptions carried out by the sovereign lies on both inside and outside the law, that also implies an illegal act which symbolizes the legal system (Murray \& Whyte, 2011: 186).

State plays a major role in shaping individuals in it. Likewise, individual also plays a major role in the establishment of a country. So, in citizenship, the state must fulfill its responsibility as a country to individuals in it as citizens, and so do citizens, they must comply with the regulations made by state. However, the way of an individual to comply with state regulations does not guarantee state's acknowledgement and protection upon. The relationship between the state and its citizens depicted in Go Set A Watchman becomes the image of reality of USA and its people.

Based on the phenomenon, several problems regarding the relationship between USA and its citizens have raised, as described in the novel Go Set $A$ Watchman. The relationship is based on the point of view of Agamben's theory regarding state sovereignty. The formulations are as follow:

1. How does Go Set A Watchman represent racism in the socio-political life of USA which described in the novel?

2. How the operation of state of exception in racism phenomenon within socio-political life of USA which described in the novel? 
The purpose of this research is to find out of how the state of exception is operated in racism issues in USA, and how it affect the life of individual within, through the novel Go Set A Watchman, and also to reveal the image raised by Go Set $A$ Watchman towards the relationship between USA as the state and Americans as the citizen.

\section{RESEARCH METHODS}

There are two types of data as object of research; formal and material. The formal object is political sociology which focused on literary works as a reflection of society as the research theory. The material object is Go Set A Watchman, a novel by Harper Lee which published in 2015.

The first method in collecting the data was through intensive reading to the literary work, to find the fragments of text within the novel that depict significant biopolitics practices. Second method was observing real issues in American society to manifest a sociological study of literature.

Furthermore, the analysis was conducted in descriptive analysis method, started from exploring the political atmosphere of USA in the 21 st century and its forms. Thus, how the biopolitics operate and what forms of biopolitics develop in USA were clearly seen. Then, the next step was exploring biopolitics practices in the novel and how it affected the lives of the characters.

In the last stage, the problems in this study were summarized then concluded. Research findings were revealed as the answers to questions on problem formulation.

\section{RESULTS AND DISCUSSION}

Americans are allowed to live their life as their wishes. For example, in worshipping or having certain faiths, to have and use certain thoughts to express their socio-political view, to demand the government of something, to read and print what they want, and to keep the government from interfering their private life (Epstein $\&$ Walker, 2004: 101). Freedom has many aspects, starts from freedom of speech and spread their opinion, access to information including state policies, access to infrastructure, to the ownership of guns. Yet, the freedom comes in exceptions, in form of discriminations, or specifically a racial discrimination referring to the novel Go Set A Watchman by Harper Lee.

In general, discrimination refers to different treatment for a person based on his affiliation with certain groups, which is then refined by the Supreme Court (United States of America) as a matter that appeared fair but may be different in interactions. Discrimination can be interpreted as differentiating treatment, intentionally or automatically, and differentiating the way of interactions without basis (Reskin, 2012: 19).

Racial discrimination can be further interpreted as an act of differentiating treatment based on certain racial groups. Racial discrimination in the USA exists in almost all aspects of state-living. One of the aspects of racial discrimination is in education. Formal education is the basic for someone's skill to be formally recognized as well. In addition, formal education also becomes an effort in self development for an ideal life. Unfortunately, formal education in USA is not open to all citizens.

The limitation of equal formal education for all Americans is based on the assumption of white people regarding the intellectuality of black people. Whites put their intellectuality as the standard, and assume that blacks do not have the ability to think and work in that ideal. Lee put a slight whites assumption of blacks intellectuality as follow

"I don't know what you're talking about, Jean Louise. There are a lot of truths in that book." 
"Yes indeed," said Jean Louise wryly. "I especially liked the part where the Negros, bless their heart, couldn't help being inferior to the white race because their skulls are thicker and their brain-pans shallower-whatever that means-so we must all be very kind to them and not let them do anything to hurt themselves and keep them in their places. Good God, Aunty-"

(...)

Her aunt was silent, and Jean Louise continued: "I was real impressed the parable where since the dawn of history the rulers of the world have always been white, except Genghis Khan or somebody - the author was real fair about that-and he made a killin' point about even the Pharaohs were white and their subjects were either black or Jews. "' (Lee, 2015: 102-103)

From that point can be concluded that a form of discrimination against black people is the assumption that blacks naturally have low intellectuality because of their biological factors, as if their intellectuality will never change or develop.

Discrimination through comparison is usually carried out to separate, rather than to recognize (Goldberg, 2011: 742). The construction of assumption by considering brain ability as biologically different is done to separate white and black people in various aspects of life. Discrimination is built upon performance assessments based on racial identity. Identity performance is a recognition of individuals or experiential discrimination through individual habits and styles associated with their group identity, rather than being compared as individual characters (Goldberg, 2011: 736). As in the above quote, intellectual inability is used as an identification form of black identities, resulting in various ways of separation.

Liu (2015) mentioned that the discursive cut and separation regime is operative in the economy and management of things. The regime of cut by means the logic of separation and exception studied by Agamben. Then, the law of separation and partition is inscribed in logos, and the economy and management of things is based on this law. Every separation contains or preserves within itself a sacred and unquestionable core, and language is the mediation that exercises the operation of the separation (85-87).

The separation through performance recognition by race in American society that need to be highlighted is in education. Recognizing the performance of black people as a group that is identified as low ability then becomes the basis for discrimination in their opportunities for equal education. The discrimination then precisely creates a stark difference in academic competency between black and white people. This actually strengthens the recognition of black people built by white people, that their intellectuality is indeed low.

National Center of Education Statistics records the result of reading and math test for elementary school students from 1978-2008. The results show fluctuations in racial differentiation with the minimum point is in late 1980s when schools were the most integrated (Reskin, 2012: 21).

An information on http://www.loc.gov mentions Tuskegee Institute. It is a higher education institution founded by Booker T. Washington, as the first higher education institute for black Americans. Washington aims to equip its students with academic and vocational skills so that they can share their knowledge to African Americans in South American countries. Graduates from the Tuskegee Institute are expected to hold basic skills and formal education as African American 
citizens so that they can improve their economic and social life. Thus, it shows that before the Tuskegee Institute founded, the number of black American citizens who are able to continue their education to university and gain legitimacy for their formal skills is obviously low. In fact, higher education (universities) was not open to all American citizens equally, thus a black citizen opened a special school for African Americans to fix the underdeveloped education of black citizens.

Tuskegee was mentioned on the novel as the background of Calpurnia's grandson. Calpurnia was Jean Lousie's black nanny.

\section{So, it was Frank. Of all multifarious descendants, Calpurnia took most pride in Frank. He was on the waiting list for Tuskegee Institute. He was a born plumber, could fix anything water run through. (Lee, 2015: 157)}

Frank becomes a Tuskegee student candidate and indeed the pride of his family. He has skill that require legitimacy to be rewarded professionally. The formal legitimacy of skill is needed to avoid doubts from whites regarding blacks intellectuality and working skills.

Educational institutions are part of state apparatus that perform their function as learning platform, in this case is for American citizens. Thus, the state apparatus has neglected the right of black citizens to study just like white citizens. The neglection of the right to study has performed based on affiliation to certain racial groups. In other words, the government performs exceptions regarding anti-discrimination regulations towards black people by racial exception against black people in education, through state educational institutions.

Apart from the assumption that white people have better intellectuality, white people also majority sufficient financially. In American history, blacks belonged to whites and were employed without a salary as slaves. As mentioned by Agamben (2016), the slave is not productive of her own terms - her used body is only negatively included in the political sphere and the private household. Positioned outside of life within the biopolitical community, the slave 'renders possible for others the bios politikos, that is to say, the truly human life' (20). Regarding that, blacks' spaces are restricted and limited while whites can use whatever they have to get bigger access to funds, so they also able to get higher and better education compared than blacks. Furthermore, Agamben identifying the figure of the slave as the ideal typical example of how the instrumental use of the body keeps the biopolitical machine in motion (Richter, 2019: 387)

The discriminations presented above then can be the inference that the root of the problem is educational discrimination. Discrimination in education towards blacks occurs due to two factors: the perception of the low intellectuality of blacks and the low economic capability of blacks. By discrimination in education, blacks also experience discriminations in other fields such as social life, law, politics and government. These discriminations are the manifestation of neglect of state through its apparatus towards the rights of blacks as citizens. The exception that occurs is that Americans freedom, equality, and protection from discrimination that applies to all citizens have been guaranteed, except for black citizens. The forms of protection can occur in protecting the rights of citizens and maintaining state's security as a safe place to live. One of citizens' rights is freedom of life which is guaranteed by state and protected by the constitution.

Furthermore, upper and middle class society of USA are dominated by white citizens, while black citizens dominate the lower class thus become minority in above 
social classes. Respectable and honorable men are all whites, because these men have opportunities for self-actualization such as wealth, education, family background, and privilege to express themselves in forums. In contrary, black men opportunities for self-actualization are limited. The social background and history of blacks as slaves made it less likely that they would raise a lot of money. The matter of reputation and respectable men of society also described on the novel, as follow:

... but they were sitting all over the courtroom. Men of substance and character, responsible men, good men. Men of all varieties and reputation... it seemed that the onlu man in the county not present was Uncle Jack. (Lee, 2015: 110)

After slavery had ended, discrimination against them continued, thus limiting their opportunities for education. This matter then impacted on selfactualization of each racial group community members, so that giving such an image that both group do not have same quality. Thus a binary opposition was formed between whites as a group of respectable and good reputation, while blacks are in total opposite.
Moreover, government do not interfere in restoring the rights of blacks. Even though USA has ended slavery, a new style of enslavement has been formed by not giving blacks citizenship rights to the fullest. This is a clear image of politics of neglect by USA upon black citizens. The way the novel describes a black defendant whom depicted as someone who are likely to never be free from law charges brings the conformity of how the discrimination takes place:

Atticus Finch rarely took a criminal case: he had no taste for criminal law. The only reason he took this one was because he knew his client to be innocent of the charge, and because of halfhearted, court-appointed defense. The boy had come to him by way of Calpurnia, told him his story and had told him the truth. The truth was ugly.

Atticus took his career in his hands, made good use of a careless indictmen, took his stand before a jury, and accomplished what was never before or afterwards done in Maycomb County: he won an acquittal for a colored on a rape charge. The chief witness for the prosecution was a white girl. (Lee, 2015: 109)

Meanwhile, white defendants are likely to escape the law, as presented under the character of Joshua Finch:

"Cousin Joshua was frustrated by the authorities when he fired upon the president of University, who in his opinion was little more than a sewage disposal expert. This was no doubt true, but an idle excuse for assault with a deadly weapon. After much passing around of money Cousin Joshua was moved across the tracks and placed in the state accommodation for the irresponsible, where he remained for the rest of his days." (Lee, 2015: 5)

Joshua was Jean Louise cousin who killed the chancellor of university where he studied. Instead of sent to the jail, Joshua was sent to asylum. He avoided the conviction by paid a lot of money and transferred to a mental institution. Even though he had been convicted and sentenced, a white defendant with homicide case still has the possibility to escape from prison. It shows the flexibility of the state in dealing with its citizen, particularly a white, that likely will never 
happen to a black. This assumption goes to the case attended by Finch who defend a black suspect with rape indictmen, that then known as a baseless slandering, only because the man is black and the witness is a white girl.

The chance of escaping from a verdict and sentence for blacks is close to zero, as implied by the quotation above that mentioned something spectacular, the first and last occassion in Maycomb, where a black defendant was acquitted from criminal charges. It also implies that USA government acommodates white's concerns, particulary in economical point of view, so there is the state of exception of USA towards the citizens. The base of the assumption that state apparatus practically have the intention to infringe its own regulation on law enforcement, refers to the VI Amendment regarding the guarantee for legal assistance which stated:

In all criminal prosecutions, the accused shall enjoy the right to a speedy and public trial, by an impartial jury of the State and district wherein the crime shall have been committed, which district shall have been previously ascertained by law, and to be informed of the nature and cause of the accusation; to be confronted with the witnesses against him; to have compulsory process for obtaining witnesses in his favor, and to have the Assistance of Counsel for his defense.

However, not all attorneys will objectively defend and investigate cases involving black people. Thus, advocates as government legal officers neglect black people in the half-hearted effort to defend them. As a result, a black who was not necessarily guilty was accused. Legal justice became something that was rarely found in cases of whites against, vice versa.

In other case, white citizens perform discrimination to dominate the government,

The right of citizens of the United States to vote shall not be denied or abridged by the United States or by any State on account of race, color, or previous condition of servitude ...

However in the practices, the scope of freedom for blacks is limited by suspension of their citizenship rights, as described on the novel:

"Do right?"

"Yes sir. Give 'em a chance."

"The Negroes? You don't think they have a chance?" "why, no sir."

"What's to prevent any Negro from going where he pleases in this country and finding what he wants?"

"That's a loaded question and you know it, sir! I'm so sick of this moral double-dealing I could-" (Lee, 2015, p. 241-242)

"Now think about this. What would happen if all the Negroes in the south were suddenly given full civil rights? I'll tell you. There'd be another Reconstruction. Would you want your state governments run by people who don't know how to run 'em? Do you want this town run by-no wait a minute-Willoughby's a crook, we know 
that, but do you know any of Negro who know as much as Willoughby? Zeebo'd probably be Mayor of Maycomb. would you want someone of Zeebo's capability to handle the town's money? We're outnumbered, you know. "(Lee, 2015: 246)

The description of how blacks assumed as incapable in handling town's money in quotation above reflects the discrimination. The strives of domination of whites in government by hindering the chance of blacks to take part, reflected on how the citizens council of Maycomb was created to accommodate the aspirations of Maycomb community leaders to reject the involvement of blacks. When blacks tried to enter the government by becoming lawyers and formed an organization called the
NAACP. In the story, NAACP was providing full protection to black citizens who stumble over legal cases, and whites saw this as a threat so they formed a citizen council to deal with it.

Then, the strive to minimalize the role of blacks in government in order to protect the sovereignty of the state that fully preserves the interests of white citizens and secures the places of state apparatus that might be taken over by black citizens as in the following passage:

"Hank, I suspect when we know all the facts in the case, the best that can be done for the boy is for him to plead guilty. Now, isn't it better for us to standup for him in the court than to have him fall into the wrong hands?"

A smile spread slowly across Henry's face. "I see what you mean, Mr. Finch."

"Well, I don't," said Jean Louise. "What wrong hands?"

Atticus turn to her. "Scout, you probably don't know it but NAACPpaid lawyers are standing around like buzzards down here waiting for things like this happen-"

"You mean colored lawyer?"(Lee, 2015:148-149)

The passage clearly depicted of how the freedom to take part in political field was not an easy catch for black citizens. They were not getting the chance to show their political capability, thus needed to build a particular organization that help to guarantee their freedom in politics.

The ignorance of black citizens regarding law becomes the crack for white citizens as state apparatus to carry out their exceptions in court. In other words, the rights of black citizens do not get recognition from the state through its apparatus.

Even so, state officials which dominated by white citizens took preventive measures so that the political freedom of black citizens was limited. These efforts were made to keep the sovereignty of the country in whites hands. In the strive to protect it, state apparatus violated the guarantee of political freedom for every citizens. In other words, state has neglected the political freedom of black citizens. The state stands outside the law and doing the exception toward the law itself through actions taken by the apparatus as the driving force of government and decision makers.

Discrimination against black citizens does not only occur in law and politics of state, but also occurs in everyday life. Social justice as government regulation in law of state seems unable to break down the walls of racial discrimination in American society. Blacks who work as cooks in white people's homes needed a license, of course limits their freedom of work. In addition, black people are not allowed to look at white people because they are considered impolite, indicating the existence of social injustice for black people.

Restriction of space carried out by state apparatus (eq. : Sheriffs) and 
regulations by requiring license for black citizens is acted outside the law where freedom and equality should be enforced as state law. This extrajudicial action is a state sovereignty run by its apparatus which is part of exception, the state guarantees freedom and equality without discrimination except against black citizens, thus forming a naked black life without civil and political rights and social equality. Black people only get their right to exist but not to have a state.

Discrimination against black citizens is an exception to freedom, equality, and civil rights as citizens which should be guaranteed by the government, as written in the XIV Amendment on the www.archives.gov page as follows: All persons born or naturalized in the United States, and subject to the jurisdiction thereof, are citizens of the United States and of the State wherein they reside. No State shall make or enforce any law which shall abridge the privileges or immunities of citizens of the United States; nor shall any State deprive any person of life, liberty, or property, without due process of law; nor deny to any person within its jurisdiction the equal protection of the laws.

USA which is dominated by white citizens as a state apparatus discriminates black citizens in terms of civil rights or the rights for election. The above quotation proposes that black Americans have the right to vote in elections. However, discriminations are developed on the assumption of black people's incapability and lack of intellectuality that led to the distrust over the accountability of their decisions, which later likely allowed the occurrence of political instability. Blacks' intellectuality which left behind the whites is an accumulation of discrimination that comes from the assumption, yet becomes the identity of black citizens.

\section{CONCLUSION}

Go Set a Watchman presents the picture of the relationship between USA as the state and its citizens. The state which is obliged to protect the citizens from threats of both inside and outside the country actually becomes a threat to its citizens also. Not only shows the inability of USA to fulfill its obligations to its people, this novel also illustrates that America's laws on equality and anti-discrimination have no significant impact on society. Discrimination is still described as prevalent in this novel, even conducted by government officials. Thus, this novel is very likely to be used as an educational tool for American people to be aware of their rights as citizens, to fight for it when needed. In addition, this novel can also be viewed as a criticism towards American government for its connection to discrimination of rights, particularly racial discriminations towards blacks. This novel pictures of how discriminations occur in American society in the 1960 s to the world's attention.

Theoretically can be concluded that although Agamben's political philosophy is formulated by observing some models of government in European countries, this theory is relevant with the conditions of government outside Europe. This theory describes the practice of sovereignty establishment in general, so that it can be used as a reference to examine the procedure on forming a country's sovereignty or power. In addition, this theory can also be used to see the relationship between state and its citizens. Agamben's political philosophy theory also practical in finding the forms of human existence in a country based on political rights. 


\section{ACKNOWLEDGEMENT}

Writers would like to thank

Ministry of Research and Technology /

National Research and Innovation Agency for funding this research in the scheme Penelitian Dosen Pemula for 2020 budget.

\section{REFERENCES}

Agamben, Giorgio. (2016). The Use of Bodies. Stanford, CA: Stanford University Press.

Ariesta, Fanny. \& Liliana, Muliastuti. (2017). Diskriminasi Ras dalam Film The Help Karya Tate Taylor (Kajian Feminisme). BAHTERA: Jurnal Pendidikan Bahasa dan Sastra. Vol. 16, 47-55.

Brown, Holy Cade. (2017). Figuring Giorgio Agamben's "Bare-life" in the Post-Katrina Works of Jesmyn Ward and Kara Walker. Cambridge University Press and British Association for American Studies. Vol. 1, 1-19.

Frost, Tom (2010). Agamben's Legalization of Foucault. Oxford Journal of Legal Studies. Vol.30, 545-577.

Frost, Tom. (2019). The Dispositif Between Foucault and Agamben. Law, Culture and the Humanities, 15 (1). 151-171. ISSN 1743-8721.

Goldberg, B. Suzanne. (2011). Discrimination by Comparion. The Yale Law Journal. Vol. 120, 728-812.

Gordon-Zolov, Tery, and Robin Roger. (2010). Introduction: Citizenship. Women's Studies Quarterly. Vol. 38, 13-24.
Grotenhuis, Rene. (2016). Nation Building as Necessary Effort in Fragile State. Amsterdam: Amsterdam University Press.

Lee, Harper. (2015). Go Set A Watchman. NY: Harper Collins Publisher.

Liu, Joyce C.H. (2015). Against Agamben; Sovereignty and the Void in the Discourse of the Nation in Early Modern China. Theory, Culture, \& Society. Vol 32 (4), 81-104.

Murray, Alex and Jessica Whyte. (2011). The Agamben Dictionary. Edinburgh: Edinburgh University Press Ltd.

Reskin, Barbara (2012). The Race Discrimination System. Annual Review of Sociology. Vol.38, 17-24.

Richter, Hannah. (2019). The Eroticization Of Biopower: Masochistic Relationality and Resistance In Deleuze and Agamben. European Journal of Social Theory. Vol.22 (3), 382-398.

Villamizar, German E.P. (2014). Potentiality, Sovereignty and Bare Life A Critical Reading of Giorgio Agamben, Ideas Y Valores. Vol. 63, 79-99.

http://www.loc.gov/exhibits/odyssey/educ ate/bookert.html accessed at October 18,2020

https://www.naacp.org/oldest-and-boldest/ accessed at October 18, 2020

https://www.archives.gov/foundingdocs/bill-of-rights-transcript accessed at October 18, 2020 